International Journal on Emerging Mathematics Education (IJEME)

Vol. 1, No. 1, March 2017, pp. 1-10

P-ISSN: 2549-4996, E-ISSN: 2548-5806, DOI: http://dx.doi.org/10.12928/ijeme.v1i1.5507

\title{
Development of Student Worksheets to Improve the Ability of Mathematical Problem Posing
}

\author{
1,2Harry Dwi Putra, 2Tatang Herman, 1,2Utari Sumarmo \\ 1STKIP Siliwangi, Jl. Terusan Jend. Sudirman No. 3 Baros, Cimahi Tengah 40526 \\ 2Universitas Pendidikan Indonesia, Jl. Dr. Setiabudhi No. 299, Bandung 40154 \\ Email: harrydp.mpd@gmail.com
}

\begin{abstract}
Abstrak
Aktivitas mengajukan masalah (problem posing) dan menyelesaikannya merupakan bagian penting dari matematika, sehingga problem posing merupakan aktivitas yang sangat berperan dalam berpikir matematis dan menjadi bagian yang penting dalam pemecahan masalah. Jenis penelitian ini adalah research and development yang bertujuan untuk mengembangkan lembar kerja siswa mengenai aturan pencacahan dengan pendekatan scientific disertai strategi what if not. Metode penelitian terdiri dari: studi pustaka, observasi, wawancara; pengembangan bahan ajar, penilaian dari dua ahli, dan uji coba terbatas pada siswa kelas XI di SMAN 2 Cimahi, SMAN 3 Cimahi, dan SMAN 4 Cimahi. Berdasarkan hasil penelitian, diperoleh lembar kerja siswa yang memuat aktivitas mengamati, menanya, mencoba, menalar, dan menyimpulkan. Pada aktivitas menanya menggunakan strategi what if not dengan cara merubah data, menambah data, mengubah data dengan pertanyaan yang sama, atau mengubah pertanyaan dengan data yang sama. Dalam lembar kerja disajikan masalah kontekstual yang sesuai dengan pengalaman siswa. Setelah dilakukan uji coba menggunakan lembar kerja, peningkatan kemampuan mathematical problem posing siswa pada ketiga sekolah berada pada kriteria sedang.
\end{abstract}

Kata Kunci: lembar kerja siswa, pendekatan scientific, strategi what if not, mathematical problem posing

\begin{abstract}
Activities posing and solving a problem are important parts in mathematics, so the problem posing is an activity that was instrumental in mathematical thinking and become an important part in solving the problem. This type of research is research and development that aims to develop student worksheets through scientific approach with what if not strategy. The research method consists of stages: literature study, observation, interviews, development of student worksheets, assessment of two experts, and restricted trial to the eleventh grade students in SMAN 2 Cimahi, SMAN 3 Cimahi, and SMAN 4 Cimahi. Based on the findings, it was concluded that the student worksheets through scientific approach with what if not strategy load some activities including observing, questioning, trying, reasoning, and concluding. The activity of questioning using what if not strategy involves changing data, adding data, changing data with the same question, or changing question with the same data. The student worksheets also presented some contextual problems in accordance with the experience of students. After tested using worksheet, the improvement of student mathematical problem posing in the three schools was in moderate criteria.
\end{abstract}

Keywords: student worksheets, scientific approach, what if not strategy, mathematical problem posing

How to Cite: Putra, H.D., Herman, T., \& Sumarmo, U. (2017). Development of student worksheets to improve the ability of mathematical problem posing. International Journal on Emerging Mathematics Education, 1(1), 1-10. http://dx.doi.org/10.12928/ijeme.v1i1.5507.

\section{INTRODUCTION}

The heart of mathematics is to pose problems and solve them (Brown \& Walter, 1990). Therefore, the problem posing activity become an important role in 
mathematical thinking and become an important part on problem solving. Based on some findings, Winograd (1997) suggested that giving assignments to the students to create questions could improve the ability to solve problems and their attitudes toward mathematics. In line with this finding, English (1998) stated that the problem posing could improve thinking skills, problem solving, attitude, confidence in solving problems, and generally contribute to the understanding of mathematical concepts. To acquire the ability of problem solving, students should have many experiences in solving various problems (Herman, 2007).

Mathematics learning in senior high school should load tasks to formulate mathematical problems based on various situations, both inside and outside mathematics, organize and find conjecture, and learn to generalize and extend the problem through problem posing (NCTM, 2000). To develop the ability of mathematical problem posing, we required the ability to creating new questions, creating new opportunities, and looking at old questions from a new angle (Ellerton \& Clarkson, 1996). This opinion is supported by Silver (2013) who states that the relationship between creativity and posing problems does not stand alone but affects each other. After made questions, the students were asked to check the accuracy of the questions answered. These activities could train the students to think reflectively.

Problem posing is not only seen as a purpose of learning but also as a tool that can provide experiences for students to find and to create mathematical problems. This experience is still a bit possessed by students. According to the findings of Van Harpen \& Sriraman (2013) advanced high school students had trouble posing good quality and novel mathematical problem. Joo \& Han (2016) revealed that some senior high school students had difficulties in posing problem or limited understanding of that. Igor (2016) found that the problem posing performance of senior high students and the teachers was the low quality of the created problems. Therefore, the ability of problem posing should be trained to the students in order to develop the ability to think, to be skillful to troubleshoot, and expand the understanding of the concept. If the teacher presents a challenging problem and requires students to think, then the situation can provide greater opportunities for students to develop critical thinking.

In the curriculum of 2013 emphasizes on a contextual approach becomes the process approach as strengthening of the use of scientific approach. The scientific approach is one of the approach that facilitates students to acquire knowledge and skills based on a scientific method: observing, questioning, reasoning, trying, and forming networks (concluding, presenting, and communicating). Students are directed to process knowledge, discover and develop their own concepts with regard to the subject matter so that it provides an opportunity for students to cultivate high-level thinking skills (Kemdikbud, 2013).

Brown \& Walter (1990) stated that generally mathematical thinking begins with given statements so that we just trained to resolve the issue of the statement. However, it should be better if we give another statement rather than just accept the statement. In mathematical thinking, posing a problem is better than just finishing that problem. One of the learning strategies that can develop the high-level ability of mathematical thinking is what if not strategy. This strategy can develop mathematical problem posing abilities through activities of students in analyzing problems, contrasting conditions on the problem, and checking the correctness of completion.

Based on the explanation above, it seems that the ability of mathematical problem posing for students is so important that teachers need to develop student worksheets through appropriate learning approaches and strategies in order to

IJEME, Vol. 1, No. 1, March 2017, 1-10 
improve the ability of the high-level mathematical thinking. The research questions of this study are formulated as follows: How to develop student worksheets through a scientific approach with what if not strategy to improve the students' ability of mathematical problem posing? What is the impact of the use of student worksheets through a scientific approach with what if not strategy on the students' ability of mathematical problem posing?

\section{RESEARCH METHOD}

This research is a research and development that produces student worksheets through scientific approach with what if not strategy to improve the ability of mathematical problem posing for students in senior high school. The procedures of this research include (Sukmadinata, 2012): a field survey to obtain information from the teachers in a certain school about mathematical problem posing abilities of the students. Literature review to examine the student worksheets that will be developed through a scientific approach and strategy of what if not. Drafting of student worksheets that will be assessed by a team of experts. The worksheets that had been validated were then tested to eleventh grade students from three schools, which have high, medium, and low criteria of senior high school namely SMAN 2 Cimahi, SMAN 3 Cimahi, and SMAN 4 Cimahi. Research procedure shown in the following Figure 1.

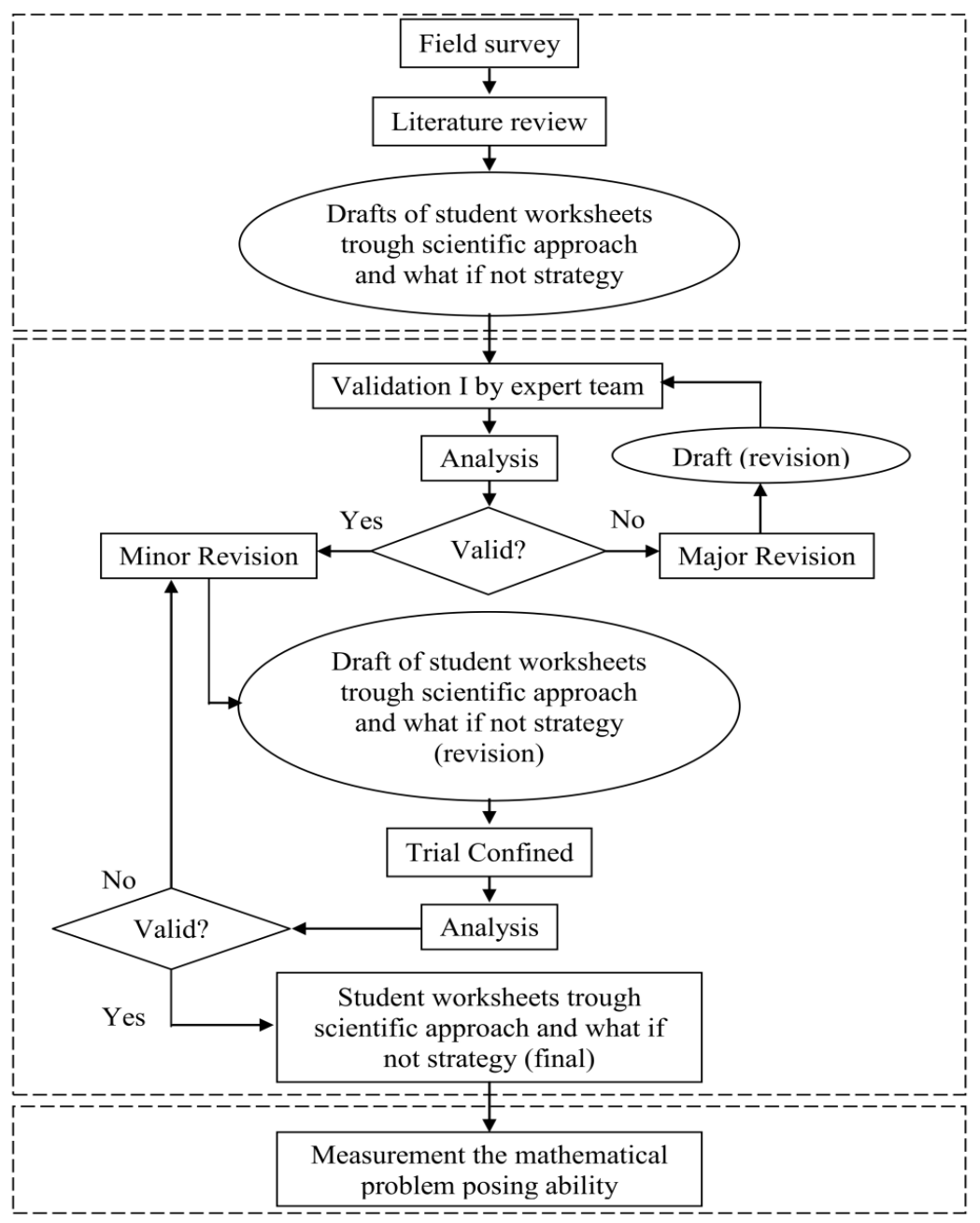

Figure 1. The Procedure of Learning Materials Development Research 


\section{RESULTS AND DISCUSSION}

Based on literature review, it can be obtained some indicators of the ability of mathematical problem posing to the material of enumeration rules. In making question dealing with the ability of mathematical problem posing for enumeration rules pertaining to matter, it refers to the following indicators (Sumarmo, 2015). Draw up a new question regarding to the problem of enumeration rules. Express a problem into another form that has the same meaning with the material of cyclic permutation. Ask questions of a series of mathematical semi-structured information with respect to the ability to think reflectively on the material of permutations. Specify the questions about the material of combination into question parts. Ask questions before, during, and after solving problems with regard to the material of chances.

According to interviews with teachers in SMAN 2 Cimahi, SMAN 3 Cimahi, and SMAN 4 Cimahi, students still had difficulty in solving the problems of permutations and combinations within the rules enumeration. They were confused on using permutation or combination formula to solve the problems. Presentation of the material from the book makes students follow the example of completion of the given problem, so that when the questions were changed, they become confused to define the concepts to use whether it is permutation or combination. In lessons, students rarely ask questions. That was only teachers who posed the question to the students. This shows that the students' ability to pose a problem was undeveloped.

One of the appropriate approaches is scientific approach with what if not strategy. In the opinion Brown \& Walter (1990) to develop the ability of problems posing, we can use a what if not strategy by changing the data in question, adding data on the problem, changing the data with the same question, or changing the question with the same data on the problem. Based on observations and interviews conducted to teachers at those three schools, it can be concluded that the worksheets need to be developed through a scientific approach with what if not strategy to improve the ability of mathematical problem posing of high school students.

The initial design of student worksheets includes three parts. The front part consists of a title page, preface, and a table of contents. Displays the title pages of the student worksheets are made. The body section consists of a crosshead of the enumeration rules that represent the content of the chapter: rule multiplication, permutations, combination, Binomial Newton, and Chance. At the beginning of the presentation of the material given the problems that exist in daily life of the students were resolved by the given instructions to find the concept. The conclusion sections, students give reflection and evaluation of the presentation material on worksheets that they used to work on in order to make improvements. Student worksheets were adjusted to the scientific approach that includes activities to observe, ask, try, reason, and concludes. These activities can vary the sequence.

Amati permasalahan mengenai nomor antrian berikut ini.

Seorang petugas bank ingin mencetak nomor antrian nasabah yang terdiri atas tiga angka dari angka 1, 2, 3, dan 4. Berapa banyak pilihan nomor antrian yang dapat dibuat dari:

a. Tiga angka pertama?

b. Empat angka yang tersedia?

Figure 2. Observation Activity on Worksheets

IJEME, Vol. 1, No. 1, March 2017, 1-10 
In the observation, problems were presented as an introduction to the concepts to be learned. In the figure 2, students observe the problems regarding the bank officer who want to print the costumer's queue number consisting of three numbers of $1,2,3$, and 4 . The question is how much the queue number choices can be made from the first three digits? How much the queue number choices can be made from the four numbers are available?

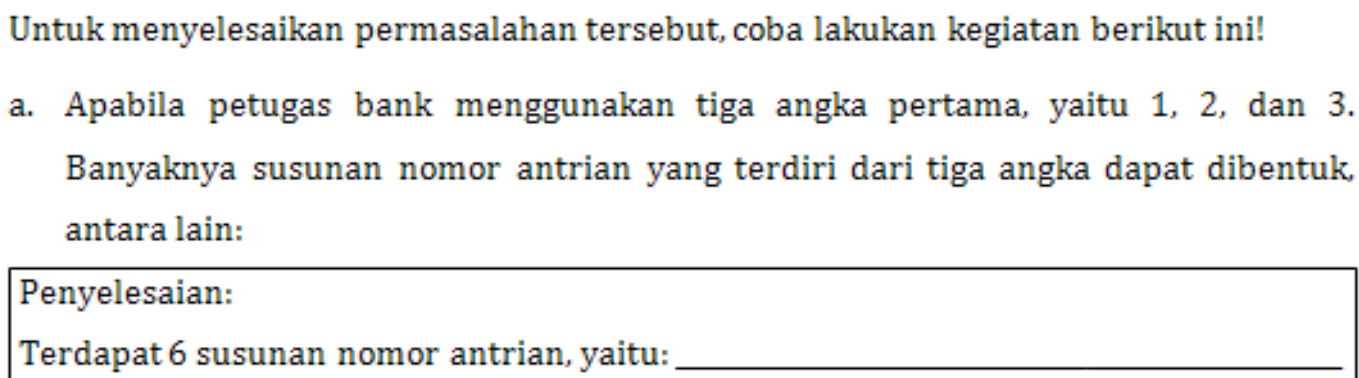

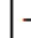

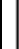


divided by 1 the result is the number itself, so $3 \times 2 \times 1=\frac{3 \times 2 \times 1}{1}$. Based on the concept of factorial, $3 \times 2 \times 1$ pattern can be written as 3 ! so $\frac{3 \times 2 \times 1}{1}=\frac{3 !}{1 !}$. Karena 1 ! equal to $(3-3)$ ! so $\frac{3 !}{1 !}=\frac{3 !}{(3-3) !}$. If students can explain the truth of the answers, it means that the students already understand the concept of factorial.

Susun dua pertanyaan baru dari permasalahan mengenai nomor antrian di atas. Kemudian, pilih satu pertanyaan yang baru tersebut dan selesaikan disertai dengan penjelasan aturan yang digunakan!

Pertanyaan:

1.

2.

Figure 5. Questioning Activity on a Worksheets

In the questioning activity, students ask two more questions about these problems. Then, students choose one question and answer it. Students can use what if not strategy to ask questions. When a bank officer would like to print the costumer's queue number consists of 4 numbers from 1, 2, 3, 4, and 5 . The questions are:

1. How much the queue number choices can be made from the first four digits?

2. Is it true that a lot of the order that can be made from 5 digits available is 120 compositions?

Perhatikan konsep faktorial berikut ini:

a. Banyaknya susunan 3 angka berbeda dari 3 angka yang tersedia adalah:

$$
\begin{aligned}
& 6=3 \times 2 \times 1=\frac{3 \times 2 \times 1}{1}=\frac{3 !}{1 !}=\frac{3 !}{(3-3) !}=3 ! \\
& \frac{3 !}{(3-3) !}=3 ! \text { artinya, permutasi } 3 \text { unsur berbeda dari } 3 \text { unsur yang tersedia, } \\
& \text { disebut juga dengan permutasi } 3 \text { unsur. }
\end{aligned}
$$

Ditulis dengan: $P(3,3)={ }_{3} P_{3}=P_{3}^{3}=3 \times 2 \times 1=3$ !

Buatlah kesimpulan mengenai konsep permutasi yang telah Anda pahami!

Kesimpulan:

Banyak permutasi $k$ unsur ditulis dengan:

Figure 6. Concluding Activity on a Worksheets

IJEME, Vol. 1, No. 1, March 2017, 1-10 
In the conclusion activity, students make inferences about the concept was studied. Students understand that many compositions can be formed from 3 different numbers of 3 numbers available are called permutations 3 elements are indicated by the symbol $P(3,3)={ }_{3} P_{3}=P_{3}^{3}=\frac{3 !}{(3-3) !}=3$ !. Many compositions can be formed from 3 different numbers of 4 number available are indicated by the symbol $P(4,3)={ }_{4} P_{3}=P_{3}^{4}=\frac{4 !}{(4-3) !}$. In conclusions, a lot of permutations of $k$ elements is $k$ ! and a lot of permutations of $k$ elements take from $n$ elements available is $P(n, k)={ }_{n} P_{k}=P_{k}^{n}=\frac{n !}{(n-k) !}$.

Assessment of student worksheets according to a team of experts from the aspect of the contents had fulfilled the five elements in the scientific approach: observing, questioning, trying, reasoning, and concluding in teaching the concept of problem. From the display of student worksheets, it looks simple. Display of student worksheets had already developed a mathematical problem posing abilities of students in asking questions about new problem or developing a given problem. Based on the results of the assessment team of experts, these materials were already eligible tested on students. Here is presented the assessment of the experts.

Tabel 1. Feasibility test result of the student worksheets

\begin{tabular}{lccrc}
\hline \multirow{2}{*}{ No. } & \multirow{2}{*}{ Experts } & \multicolumn{3}{c}{ Feasibility Criteria (\%) } \\
\cline { 3 - 5 } & Content & Display & Language \\
\hline 1. & Validator 1 & 83,33 & 85,94 & 81,67 \\
2. & Validator 2 & 79,19 & 82,81 & 80,00 \\
\hline & Mean & 81,25 & 84,38 & 80,83 \\
\hline
\end{tabular}

Based on Table 1, it seems that the average ratings of student worksheets by both the validator based on the criteria of content and language is between $63.50 \%$ $83.00 \%$ that means it is feasible. While the criteria of display is above $83,00 \%$ which means it is more feasible. Therefore, worksheets are feasible to be tested on students. Student worksheets that had been assessed shown to teachers at three schools to get suggestion for further development. The worksheets can be tested, which is in eleventh grade students in Mathematics and Science classes of SMAN 2 Cimahi, SMAN 3 Cimahi, SMAN 4 Cimahi.

Student worksheets that had been validated are given to students in learning activity nine meetings. Students were given an explanation regarding to the presentation of worksheets so that they can solve the problems properly. There are five scientific activities that must be done by students: look into the subject, ask questions about the problems with the strategy of what if not, try to solve the problem, reason against the troubleshooting steps, and make conclusions from the material they had learned. After finishing studying all the material of enumeration rules in student worksheets, they were asked to fill a scale of opinion regarding to the presentation of the worksheets they had learned.

Percentage score of opinion scale of students from three schools toward the student worksheets were $67.86 \%, 65.79 \%$ and $65.14 \%$. These results were between $61.00 \%-80.00 \%$ which means that students had positive opinion toward worksheets. Students agree that the worksheets contain the task of asking questions. Student worksheets can increase their confidence to draw the questions and solve them. Table 
2 below presented the results of the pretest, posttest, and enhancement (N-gain) of the students. Ideal Maximum score is 14.

Tabel 2. Result of pretest dan posttest of mathematical problem posing ability

\begin{tabular}{cccccc}
\hline School & Total & Pretest & Posttest & N-gain & Criteria \\
\hline SMAN 2 Cimahi & 31 & 4,31 & 10,73 & 0,67 & Moderate \\
SMAN 3 Cimahi & 35 & 4,51 & 10,48 & 0,63 & Moderate \\
SMAN 4 Cimahi & 37 & 4,29 & 10,16 & 0,60 & Moderate \\
\hline
\end{tabular}

Based on Table 2, it is shown that an improvement of the ability of mathematical problem posing of the students from the third grade is moderate. Students were not accustomed to drafting a new question, stating the problem in another form with the same meaning, asking questions with regard to determining and verifying the relevant data, scanting details into the form of parts, as well as asking questions before, during, and after troubleshooting. Through this student worksheets, it can be said that the ability of mathematical problem posing of students was increased quite well.

\section{CONCLUSION}

Based on the results of the assessment team of experts and the restricted trial of student worksheets, it can be concluded that student worksheets contained the activities of observing, questioning, trying, reasoning, and concluding in accordance with the principles of the scientific approach. What if not strategy was applied to the activities of questioning, by changing the data, adding data, or changing the question. The designs of student worksheets consist of three parts. Beginning consists of a title page, preface and table of contents. The content section containing the title of the chapter on the rules of the enumeration and contextual problems that exist in the students' life. Closing as a reflection and evaluation of the material presented on student worksheets for the next revision. Student worksheets could increase the ability of mathematical problem posing in the moderate criteria.

\section{ACKNOWLEDGEMENT}

The author would like to extend thanks to the chair and staffs of the Ministry of Research Technology and Higher Education (KEMENRISTEK DIKTI) who has helped funding this research.

\section{REFERENCES}

Brown, S.I., \& Walter, I. (1990). The Art of Problem Posing (2nd ed.). Hillsdale, NJ: Lawrence Erlbaum Associates.

Ellerton, N.F., \& Clarkson, P.C. (1996). Language Factor in Mathematics Education. Alphen aanden Rijn: Kluwer Academic Publisher.

English, L.D. (1998). Children's problem posing within formal and informal contexts. Journal for Research in Mathematics Education, 29(1), 83-106.

Herman, T. (2007). Pembelajaran berbasis masalah untuk meningkatkan kemampuan berpikir matematika tingkat tinggi siswa sekolah menengah pertama. Educationist, 1(1), 47-56.

Igor, K. (2016). Considerations of aptness in mathematcial problem posing: students, teacher, and expert working on billiard task. Far East Journal of Mathematical Education, 16(3), 243-260.

IJEME, Vol. 1, No. 1, March 2017, 1-10 
Joo, H., \& Han, H. (2016). The analysis of middle school students' problem posing type and strategies. The Mathematical Education, 55(1), 73-89.

Kemdikbud. (2013). Pendekatan Scientific (Ilmiah) dalam Pembelajaran. Jakarta: Pusbagprodik.

Kontorovich, I. (2016). Considerations of aptness in mathematcial problem posing: students, teacher, and expert working on billiard task. Far East Journal of Mathematical Education, 16(3), 243-260.

NCTM. (2000). Principles and Standards for School Mathematics. Reston, VA: National Council of Teacher Mathematics.

Silver, E.A. (2013). Problem posing reseach in mathematics education: looking back, looking around, and looking ahead. Educational Studies in Mathematics, 83(1), 157-162.

Sukmadinata, N.S. (2012). Metode Penelitian Pendidikan. Bandung: PT Remaja Rosdakarya.

Sumarmo, U. (2015). Mathematical Problem Posing: Rasional, Pengertian, Pembelajaran, dan Pengukurannya. Retrieved from STKIP Siliwangi: http://utarisumarmo.dosen.stkipsiliwangi.ac.id/files/2015/09/Problem-Posing-MatematikPengertian-dan-Rasional-2015.pdf

Van Harpen, X.Y., \& Sriraman, B. (2013). Creativity and mathematical problem posing: an analysis of high school students' mathematical problem posing in China and the USA. Educational Studies in Mathematics, 82(2), 201-221.

Winograd, K. (1997). Ways of sharing student-authored story problems. Teaching Children Mathematics, 4(1), 40-49. 
IJEME, Vol. 1, No. 1, March 2017, 1-10 